\title{
Violating Displaced Persons' Human Rights And Impairing The Quality Of Human Resources
}

Bruce A. Forster, Arizona State University, and The University of Nebraska at Kearney, USA Kelli E. Forster, Schneider Electric ${ }^{1}$, Burnaby, BC, Canada

\begin{abstract}
Each year wars force several millions of people to leave their homes to join the ranks of displaced persons (DPs). Displaced women and children are particularly vulnerable to risks of physical abuses. The loss in current and future human resource quality caused by abuses suffered by DPs is an extreme version of the well-known brain drain phenomenon. The paper considers the psychological damage inflicted upon DPs, the possible effects of Post-Traumatic Stress Disorder $(P T S D)$ and the consequent damage to human resource quality.
\end{abstract}

Keywords: Displaced Persons; UNHCR; UNRWA; Protracted Displacement; Post-Traumatic Stress Syndrome (PTSD)

\section{INTRODUCTION}

Displaced persons do not sleep peacefully in their beds because rough men stand ready to do violence to them. With apologies to George Orwell ${ }^{2}$

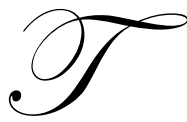

he first part of this paper updates, and substantially expands, information on Displaced Persons introduced in Forster and Forster (2010). The second section takes us into the psychology realm and considers emotional and psychological damage including PTSD. We argue that the damages to Displaced Persons, physical, emotional and psychological have an impact upon the supply of Human Resources much like a nasty version of the well-known brain drain.

The 2009 Global Monitoring Report noted that the countries making the most sluggish progress towards meeting the Millennium Development Goals are those fragile and conflict-affected states. More than half of these countries are in Sub- Saharan Africa (SSA). Collier (2007), in The Bottom Billion, comments that $73 \%$ of those people living in the bottom billion of people globally have been through a civil war or are still engaged in one. Collier refers to civil war as [economic] development in reverse. In discussing the costs of war Collier points out that many who die in civil war are not combatants killed in battle but rather civilian and other non-combatants who succumb to disease. Each year, around the world, several millions of people are forced to leave their homes involuntarily, and join the ranks of individuals known collectively as displaced persons (DPs).These mass migrations result in collapsing public health systems which, in turn, create epidemics. The civilians are also impacted physically, emotionally and mentally. Displaced women and children are particularly vulnerable to a variety of abuses.

A body of international law has evolved to protect such displaced persons and non-combatants in general during periods of armed conflict. Unfortunately, these laws frequently are ignored. This paper considers the consequent losses in current and future human capital caused by the human suffering associated civil conflict and displacement.

\footnotetext{
${ }^{1}$ The views expressed in this paper are those of those of the authors, and are not endorsed by Schneider Electric.

${ }^{2}$ Orwell's comment was "Men sleep peacefully in their beds at night since rough men stand ready to do violence on their behalf." 


\section{DISPLACED PERSONS}

We consider two major categories of DPs. Persons who leave their homes and enter foreign countries are termed "refugees". Those who, while displaced, remain within their own home countries are termed "internally displaced persons" (IDPs). For our current purposes Refugees fall into two sub-categories: those under the mandate of the UN's High Commissioner for Refugees; and a group referred to as Palestine Refugees under the UN Relief and Works Agency for Palestine Refugees in the Near East (UNRWA). Table 1 outlines the numbers of DPs and their composition from 2000 to 2009.

Table1: The Number of Refugees, and IDPs, 2001-2009 (in millions of persons)

\begin{tabular}{|l|c|c|c|c|c|c|c|c|c|c|}
\hline \multicolumn{1}{|c|}{ Year } & $\mathbf{2 0 0 1}$ & $\mathbf{2 0 0 2}$ & $\mathbf{2 0 0 3}$ & $\mathbf{2 0 0 4}$ & $\mathbf{2 0 0 5}$ & $\mathbf{2 0 0 6}$ & $\mathbf{2 0 0 7}$ & $\mathbf{2 0 0 8}$ & $\mathbf{2 0 0 9}$ & $\mathbf{2 0 1 0}$ \\
\hline Number of UNHCR Refugees & 12.0 & 10.6 & 9.6 & 9.2 & 8.4 & 9.9 & 11.4 & 10.5 & 10.4 & 10.6 \\
\hline Number of UNRWA Refugees & 3.8 & --- & --- & 4.0 & 4.3 & 4.3 & 4.6 & 4.7 & 4.8 & 4.8 \\
\hline Total Number of UN-Refugees & 15.8 & --- & --- & 13.2 & 12.7 & 14.2 & 16.0 & 15.2 & 15.2 & 15.4 \\
\hline Number of IDPs of Concern to the UNHCR & 1.2 & ---- & 4.2 & 5.4 & 6.6 & 12.8 & 13.7 & 14.4 & 15.6 & 14.7 \\
\hline
\end{tabular}

Sources: UNHCR (2002, 2004, 2005, 2006, 2007b, 2008, 2009a, 2010, 2011), UNRWA (2011)

The number of UNHCR- refugees decreased from 12 million persons in 2000 and 2001 to 8.4 million persons at the end of 2005. The trend reversed, briefly, in 2006 with an increase in refugees to 9.9 million persons by the end of the year. At the end of 2007, the number had increased to 11.4 million persons. The number of UNHCR refugees dropped again in 2008 and in 2009 to 10.4 million persons - slightly lower than the number of refugees in 2002. Over the period 2000 to 2009, the number of refugees decreased by almost 2 million people. By contrast, the number of refugees increased dramatically during the period 1975 to 1993 increasing from 2.4 million in 1975 to 18.2 million in 1993.

The number of UNRWA refugees increased slowly but steadily over the past decade by a total of one million persons over the years 2001 to 2009 . The total number of refugees, globally, declined by 0.6 million over this same period.

The number of IDPs, in Table 1, includes only those caused by conflict situations. These IDPs have shown dramatic growth from 1.2 million in 2001 to 15.6 million in 2009. In 2009, the number of conflict-induced IDPs is slightly larger than the total number of refugees covered by the two UN mandates for the first time.

\section{Refugees}

The first refugee statute was the UN Relief and Works Agency for Palestine Refugees in the Near East (UNRWA) established in December 1949 following the 1948 Arab-Israeli war. Under the UNRWA's mandate, Palestine refugees include:

Those people and their direct descendants who lived in Mandate Palestine between June 1946 and May 1948 and who lost both their homes and livelihood as a result of the 1948 Arab-Israeli war... (UNRWA, 2009a)

Concern for Europeans displaced by World War II resulted in the United Nations General Assembly issuing Resolution 319A (IV) and The Statute of the Office of the High Commissioner for Refugees which established the Office of the UNHCR effective 1950. Rights of refugees are set forth in the 1951 United Nations Convention Relating to the Status of Refugees. This Convention initially specified refugees as persons satisfying by 1951 the definition set forth in the Convention, and it implicitly concerned only persons in Europe. The 1951 Convention was modified by the Protocol Relating to the Status of Refugees (1967) which removed the time and geography restrictions imposed in the original Convention. The 1951 Convention modified by the 1967 Protocol (hereafter collectively referred to as the 1951 Convention) formally defines a refugee (under the UNHCR Mandate) as a person who: 
owing to well-founded fear of being persecuted for reasons of race, religion, nationality, membership of a particular social group or political opinion, is outside the country of his nationality and is unable or, owing to such fear, is unwilling to avail himself of the protection of that country; or who, not having a nationality and being outside the country of his former habitual residence is unable or, owing to such fear, is unwilling to return to it.

As shown in Table 1, most UN -recognized refugees are covered by the UNHCR's mandate (roughly $66 \%$ ). Table 2 presents information for the number of UNHCR- refugees from the World's major regional classifications in 2009. The three largest regions are Asia and Pacific (37\%), Sub-Saharan Africa (20\%) and the Middle East and North Africa (19\%). The total number of UNHCR-refugees was 10.4 million consistent with Table 1 results.

Table 2: Regional Distribution of UNHCR Refugees, 2010

\begin{tabular}{|l|c|c|}
\hline UNHCR Regional Source & Total Refugees (End of 2010) & \% \\
\hline Sub-Saharan Africa & $\mathbf{2 , 1 8 4 , 0 0 0}$ & $\mathbf{2 1}$ \\
\hline Americas & 804,000 & 8 \\
\hline Asia and Pacific & $4,014,100$ & 37 \\
\hline Europe & $1,606,600$ & 16 \\
\hline Middle East and North Africa & $1,941,000$ & 19 \\
\hline Overall Total & $\mathbf{1 0 , 5 4 9 , 7 0 0}$ & $\mathbf{1 0 0}$ \\
\hline
\end{tabular}

Source: UNHCR (2011)

Table 3 presents the 2009 distribution of UNRWA refugees across the five areas of its operations. Collectively, Gaza and the West Bank are referred to as the Occupied Palestinian Territory (OPT). Jordan hosted 2.0 million refugees, or $42 \%$ of the total, and the OPT countries hosted 1.9 million refugees, or $40 \%$ of the total. Syria and Lebanon hosted the remaining 0.9 million, or $18 \%$.

Table 3: UNRWA Refugees by Host Country/Region

\begin{tabular}{|l|c|c|}
\hline \multicolumn{1}{|c|}{ Region/Country } & Number of Refugees (in millions) & \% \\
\hline Jordan & 2.0 & 42.5 \\
\hline Gaza & 1.1 & 23.4 \\
\hline West Bank & 0.7 & 15 \\
\hline Syria & 0.5 & 10.6 \\
\hline Lebanon & 0.4 & 8.5 \\
\hline Total & $\mathbf{4 . 7}$ & $\mathbf{1 0 0}$ \\
\hline
\end{tabular}

Source: UNRWA (2011)

Both refugee conventions were intended to have short lives to deal with "immediate" and specific refugee problems. Ironically, both organizations have persisted for over 60 years, and today they deal with more refugees than those who originally required assistance when the two mandates were established.

\section{Internally Displaced Individuals}

IDPs are defined as:

Persons or groups of persons who have been forced or obliged to flee or to leave their homes or places of habitual residence, in particular as a result of, or in order to avoid, the effects of armed conflict, situations of generalized violence, violations of human rights or natural or human-made disasters, and who have not crossed an internationally recognized State border (UNHCR, 2007a).

The global distribution of IDPs in 2009 is given in Table 4. 
Table 4: Number of IDPs in Major regions and the Associated Regional Shares of IDPs, 2010

\begin{tabular}{|l|c|c|}
\hline \multicolumn{1}{|c|}{ Region } & IDPs (millions) & \% \\
\hline Africa (including North Africa) & 11.1 & 40 \\
\hline Americas & 5.4 & 20 \\
\hline South and South-East Asia & 4.6 & 17 \\
\hline Middle East & 3.9 & 14 \\
\hline Europe and Central Asia & 2.5 & 9 \\
\hline Total & 27.5 & 100 \\
\hline
\end{tabular}

Source: IDMC (2011)

The 11.1 million IDP figure in 2010 was a low total for Africa; however, Africa still accounted for $40 \%$ of estimated 2010 IDP population. A caution is needed here. Compared with refugees, statistical information on IDPs is inadequate. For example, the 11.1 million IDP figure for African IDPs is based on information from just 21 countries. In an earlier survey, eight countries denied the existence of IDPs caused by conflict, generalized violence or human rights violations, and 36 countries denied forced displacement of their ethnic minorities (IDMC, 2009). Up- to- date information for 2008 was available in only six countries. "For the rest, data was outdated, incomplete, or non-existent" (IDMC, 2009). Not all IDPs reside in established camps. Some migrate towards urban areas. Urban IDPs are particularly difficult to distinguish from other migrants and the urban poor. Many IDPs do not register their status in order to preserve their anonymity; however, in so doing, they also forego whatever assistance may be available for them.

There is no single international agency to champion the cause of the IDPs. Nor is there an international convention stipulating the rights of IDPs. Over the years the UNHCR was called upon to provide assistance with IDPs given the expertise it had gained in working with refugees. The IDP situation improved considerably with:

- the development of the "1998 Guiding Principles on Internal Displacement",

- the 2004 creation of the position of Representative of the Secretary-General on the Human Rights of Internally Displaced Person

- the 2005 adoption of "the Cluster Approach" which coordinated the efforts of various agencies assisting IDPs.

Also The Kampala Convention, a regional convention pertaining to the rights of IDPs in Africa. This convention could serve as a model for other regions. However, to date the Kampala Convention has been a disappointment since only four African countries have ratified the Convention. Until more countries ratify the Convention it cannot come into force.

Under the Cluster approach, the UNHCR is the lead agency and it assumes responsibility for the establishment and management of camp facilities for IDPs. The rationale offered for the absence of an international organization supporting IDPs is the principle of sovereignty which vests the responsibility for protecting IDPs in their respective domestic governments. However, this rationale falls apart when the government and its armed forces are the perpetrators of the abuse including the killing of IDPs. IDMC (2009) found that, in at least 26 countries, IDPs still faced violence within their area of refuge.

Persons covered by the 1951 Convention, the Cluster Approach for IDPs, and others receiving UNHCR assistance are termed "persons of concern" to the UNHCR.

\section{SELECTED EXAMPLES OF VIOLATIONS OF THE HUMAN RIGHTS OF REFUGEES AND IDPS}

"Women and children are throw-away items all across Africa” Cindy McCain, Morning Joe, MSNBC, March 10, 2010 .

Some of the challenges facing displaced persons are the same whether they are refugees or internally displaced persons. Women and young girls in each group are the targets for sexual abuse and physical violence with death sometimes occurring. For refugees, the UNHCR (2003) comments: 
Refugee women and girls are often subject to specific forms of abuse, such as rape, abduction, trafficking, or demands for sexual favors in exchange for protection, documents or assistance. Refugee children, especially girls are at even greater risk of sexual exploitation, violence and abuse.

Similar statements regarding IDPs are given by IDMC (2010): "Displaced women and children were exposed to rape and sexual violence in a number of countries...." and "Internally displaced children were particularly susceptible to risks associated with armed conflict...."

In a survey of 52 countries, IDMC (2009) found that internally displaced women and children were exposed to rape, sexual exploitation and gender- based violence in 18 of the countries.

When the sexual abuse comes at the hands of armed groups, the results may result in horrific, brutal deaths. Displaced women and children may experience rape and other sexual abuse from other displaced persons, family members, local authorities, and even humanitarian workers including (although rarely) UN peacekeepers. Displaced women and children are also targets for abduction and human trafficking.

Refugee and internally displaced children (male and female, and including adolescents) are targets for involuntary recruitment by armed groups and national armed forces. In IDMC's (2009) survey, IDP children were recruited into armed forces or armed groups in 13 countries.

When Displaced Persons flee their homes, they are likely to leave their belongings behind taking with them only what they can carry. Their homes may be burned after (or before) they flee as are any crop fields. Livestock is lost if not taken. The losses of physical wealth and their livelihoods (for at least a period of time) is a major challenge confronting DPs.

While displacement increases the risk of sexual -based abuse for women and girls and the recruitment of children into armed forces, it is a recognized fact that these abuses are present in conflict situations for the civilian population in general, not just those who are displaced (ICRC, 2009; HRW, 2009).

\section{Protracted Displacement}

Both refugees and IDPs, if they are displaced long enough, will inevitably be met with increased tension with the "locals" as they find themselves competing for already stressed scarce resources. The resentment fuels more abuse aimed at those displaced persons.

This heightens the importance of another challenge for both groups of DPs in determining solutions to their displacement. UNHCR (2009) estimates that there are about 5.7 million protracted refugee situations across at least 22 countries where a protracted refugee situation is defined "as one in which 25,000 or more refugees of the same nationality have been in exile for five years or more in a given asylum country" (UNHCR, 2009). The majority of global IDPs live in protracted displacement and are located in some 35 different countries where protracted internal displacement situations "are those in which the processes of finding durable solutions have stalled and/or IDPs are marginalized as a consequence of violations or lack of protection of human rights, including economic, social and cultural rights" (IDMC, 2009).

\section{POST-TRAUMATIC STRESS SYNDROME (PTSD)}

"PTSD has been with us for a long time under different names" General Michael Chiarrelli, Vice Chief of Staff, U.S. Army, on CNN's State of the Union, May 29, 2011.

Most adults in the English speaking world are likely familiar with the PTSD acronym, and have a general idea of its meaning while (perhaps) not fully understanding all of the medical implications that have been uncovered since its recognition. As General Chiarrelli comments, the phenomenon has been around for a long time but with various names. In terms of relatively recent history, the phenomenon was noted in the US Civil War, and was called Soldiers' Heart. 
In WWI the phenomenon was known as Shell Shock or possibly Combat Fatigue or, Battle Fatigue. Symptoms could lead troops to flee a battle site and then they may face accusations of cowardice or desertion. In WWI, treatment of these symptoms could be swift, and brutal. Three hundred and six British and Commonwealth soldiers were executed by firing squad for exhibiting the signs of Shell Shock. Only recently (in 2006!) have those soldiers received pardons for their behavior. Some soldiers executed were as young as 16 years of age. Gross Stress Syndrome was the term used in WWII.

In the 1970s, the medical community began to notice behavioral issues with American soldiers returning from the war in Vietnam. The phenomenon was termed Post-Vietnam Syndrome. It would take until 1980 for the phenomenon to be recognized formally by the American Psychiatry Association as a legitimate medical diagnosis, and PTSD blazed onto the scene and into our collective minds.

A relatively simple definition of PTSD is "an emotional illness that is classified as an anxiety disorder and usually develops as a result of a terribly frightening, life-threatening, or otherwise highly unsafe experience."

As the foregoing discussion highlights, PTSD and its precursors were viewed as problems confronting combatants. Since recognizing PTSD as a medical diagnosis in 1980, the medical profession has come to realize that PTSD is not a condition reserved solely for combatants. It is believed that $7 \%-8 \%$ of people in the US will suffer from PTSD in their lives, with women experiencing rates double those of males. For combatants and rape victims the rates vary between $10 \%$ and $30 \%$. Up to $100 \%$ of children who witnessed the killing of a parent or endured a sexual assault or abuse may develop PTSD (MN, undated).

HR (2007) noted that:

Being displaced can have severe adverse effects on the physical, social, emotional and spiritual well-being of a person. Exposure to violence or disaster, loss of or separation from family members and friends, deterioration in living conditions, the inability to provide for one's self and family, and the lack of access to services, can all have immediate and long-term consequences for individuals, families, and communities, including post-traumatic stress disorders, psychosomatic illness, depression, anxiety, and even violence.

Other studies have shown that the impact of sexual violence on children is associated with "lower social competence", "lower academic performance" and "lower self-esteem" (IASC, 2007).

\section{TWO HIGH-PROFILE COUNTRIES}

\section{Darfur, Sudan}

Approximately 2.5 million people from Darfur were displaced due to the civil conflict; several have become refugees in Cairo, Egypt. The Meffert and Marmar (2008) study concerning the mental health of the refugees found that a large number of Darfur refugees had "undergone intense traumatic exposure, including rape, murder of family members, and narrow escape from death". Short term impacts of the experiences of the refugees lead to many depression- related symptoms such as "hopelessness, tearfulness, apathy, decreased concentration, decreased or increased sleep, low appetite, weight loss, low mood, decreased energy, and guilt". The refugees were found to have a higher rate of PTSD and other disorders than general population due to their experiences. These "experiences may have significant negative effects on their sense of worth and general self-esteem". The study found a higher level of conflict within families (both husbands with wives and parents with children) as well as higher levels of violence amongst youth.

Without a strong support system, the result is "a lack of independence, unemployment, legal involvement, family dysfunction and disintegration, and a minimal social support system." The traumatic events that many displaced people experience prior to, or as part of their displacement, lead to many physical and mental impacts that may have lasting impact on their future livelihood and contribution to their new home once resettled. 


\section{Democratic Republic of Congo}

The Democratic Republic of Congo has earned the reputation of being the rape capital of the world. Rape is a strategic weapon of war, which is very apparent in the Congo. Many years after the civil war ended in the Congo in 2003, the trend of using rape to control, intimidate and displace citizens has not improved. For example, during the military operations against FDLR militia between Jan and October 2009, more than 1,000 civilians were killed, 7,000 women and girls were raped, more than 6,000 homes were destroyed and nearly 900,000 have been displaced and forced to live in squalid displacement camps (HRW, 2009). In a particularly cold-blooded and systematic attack in August 2010, 300 people were raped, 235 of the people were women, 52 were girls, 13 were men and 3 were boys. In the raid, 116 people were abducted.

Peterman et al. (2011) found that approximately 1.7-1.8 million women were raped in their lifetime. This report illustrated that rape is becoming more prevalent among civilians than previously thought as well as projecting that about 3.1-3.4 million women report sexual violence with their intimate partner. It has been found that over 400,000 people report being raped in the preceding year, while previous UN estimate was 16,000 in one year.

As if the brutality endured by the Congolese is not enough, migrant Congolese women along the AngolaCongo border are suffering "vicious measures" undertaken by Angolans designed to get rid of the Congolese. Between April and August 2011, Congolese women experienced some "21,000 cases of serious human rights violations including rape, beating and torture and looting" (The Economist, 2011).

\section{CONCLUSION}

As noted above, Collier states that "civil war is economic development in reverse." The major reason for this assessment is the impact that civil war has on the economy's factors of production: human resources, physical capital and natural resources.

The most obvious negative impacts on human resources occur as combat and collateral deaths. These losses are forever! The term "brain drain" refers to the loss of a country's human capital to other countries. The human capital in this case refers to the skills and educational training embodied in those leaving the country. In the typical story the individuals exit less developed countries and migrate voluntarily to more developed countries to take advantage higher compensation levels. In times of war these individuals may still leave voluntarily but the prime reason may be to relocate in safer environments (even if financial compensation is comparable to those at home). These individuals are usually highly talented and have the financial ability to move voluntarily. This voluntary migration reduces the productive labor force in the less developed countries and reduces their economic growth potential. However, in the brain drain case the amount of human capital is unchanged globally. There is just a redistribution of the global supply of human capital. Host countries benefit from the expansion of their labor pool.

Those who are involuntarily displaced, as refugees or IDPs, face other difficulties since they are at elevated risk of further safety problems discussed above. The psychological and emotional damages have long-lasting debilitating consequences that reduce their productive capabilities

The parties to the civil conflict compete for control of the country's natural resources either to fund their military exploits or to line their own pockets. Either way the resources are diverted away from socially productive use. The nature of warfare destroys physical assets including structures (housing and production facilities) which also reduce the productive capacity of affected countries.

\section{AUTHOR INFORMATION}

Dr. Bruce A. Forster holds a BA in Mathematics and Economics from the University of Guelph in Canada, and a $\mathrm{Ph} \mathrm{D}$ in Economics from the Australian National University. He is co-author of Economics in Canadian Society (John Wiley), author of The Acid Rain Debate (Iowa State University) and author of almost 50 journal articles, book chapters and special proceedings. From 1989 to 1991 Dr Forster was an Associate Editor of the Journal of Environmental Economics and Management. From 1991 to 2009 Dr. Forster served as a Business dean at the 
University of Wyoming, Arizona State University's West campus, and the University of Nebraska at Kearney. Dr. Forster retired from UNK at the end of May 2009, and holds Professor emeritus titles from UNK and ASU. E-mail: forsterba@unk.edu. Corresponding author.

Kelli E. Forster holds a BA in Psychology from the University of British Columbia. Following graduation she travelled in Ghana and Burkina Faso. She has also travelled in South-east Asia. Ms. Forster is currently a Director of Human Resources within Schneider Electric and has worked for Schneider Electric (formerly Xantrex) since 2005. From 1997 - 2005, Ms. Forster worked for Creo Inc in Vancouver, BC, Canada. E-mail: kelli.forster@gmail.com.

\section{REFERENCES}

1. Burgess, A. 2004 "Health Challenges for Refugees and Immigrants."IRSA, Research Reports, March/April.

2. Collier, P., 2007. The Bottom Billion. Oxford University Press.

3. The Economist, 2011. "Angola and Congo: Bad Neighbours". August 6, 2011. P.39

4. Forster, B.A. and Forster, J.D. 2010, Governance, Civil Conflict and Refugee Protection in Sub-Saharan Africa: A Primer. Journal of Applied Business Research. Vol.26 (3). 81-92.

5. Humanitarian Reform (HR), 2007. www.humanitarianreform.org

6. Human Rights Watch (HRW), 2009, "DR Congo: Civilian Cost of Military Operation is Unacceptable."www.hrw.org/en/news/2009/10/12/dr-congo-civilian-cost-miltary-operation-unaccept.

7. The Inter-Agency Standing Committee (IASC). (2007) IASC Guidelines on Mental Health and Psychosocial Support in Emergency Settings 2007 Geneva, IASC

8. Internal Displacement Monitoring Center (IDMC), 2009. Internal Displacement: Global Overview of Trends and Development in 2008.

9. Internal Displacement Monitoring Center (IDMC), 2010. Internal Displacement: Global Overview of Trends and Development in 2009.

10. Internal Displacement Monitoring Center (IDMC), 2011. Internal Displacement: Global Overview of Trends and Development in 2010.

11. Internal Displacement Monitoring Center (IDMC), undated. Guiding Principles on Internal Displacement. www.internal-displacement.org/guidingprinciples Retrieved on 8-20-2010.

12. Medicine Net (MN), undated www.medicinenet.com/posttraumatic stress disorder/article.htm

13. Meffert, S.M. \& Marmar, C. R.2009, "Darfur Refugees in Cairo: Mental Health and Interpersonal Conflict in the Aftermath of Genocide," Journal of Interpersonal Violence, Vol.24 (11), 1835-1848.

14. United Nations High Commissioner for Human Rights (UNHCHR), 1998. Guiding Principles on Internal Displacement. www.unhchr.ch Retrieved on 3-21-2009.

15. United Nations High Commissioner for Refugees (UNHCR), 2002. UNHCR releases 2001 global refugee statistics. Press Releases, June 18, 2002.

16. United Nations High Commissioner for Refugees (UNHCR), 2003. Agenda for Protection.

17. United Nations High Commissioner for Refugees (UNHCR), 2004. UNHCR: Sharp decline in refugees, others of concern in 2003. Press Releases, June 17, 2004.

18. United Nations High Commissioner for Refugees (UNHCR). 2005. 2004 Global refugee trends.

19. United Nations High Commissioner for Refugees (UNHCR), 2006. 2005 Global refugee trends.

20. United Nations High Commissioner for Refugees (UNHCR), 2007b. 2006 Global Trends: refugees, asylum seekers, returnees, internally displaced and stateless persons.

21. United Nations High Commissioner for Refugees (UNHCR), 2008. 2007 Global trends: refugees, asylum seekers, returnees, internally displaced and stateless persons.

22. United Nations High Commissioner for Refugees (UNHCR), 2009. 2008 Global trends: refugees, asylum seekers, returnees, internally displaced and stateless persons.

23. United Nations High Commissioner for Refugees (UNHCR), 2010. 2009 Global trends: refugees, asylum seekers, returnees, internally displaced and stateless persons.

24. United Nations Relief and Works Agency for Palestine Refugees in the Near East (UNRWA), 2009, UNRWA Fact sheet. www.unrwa.org. 